\title{
Ethnomedicinal Plants Used by Residents in Northern Surigao del Sur, Philippines
}

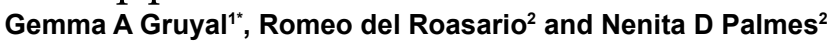

${ }^{1}$ Surigao del Sur State University, Cantilan, Surigao del Sur, Philippines

${ }^{2}$ Mindanao University of Science and Technology, Philippines

\begin{abstract}
The study was conducted to document the medicinal plants utilized for the treatment of various ailments among residents in the northern part of Surigao del Sur. The mode of preparation and treatment is also included in the documentation. Demographic and ethnobotanical knowledge was gathered through interviews using a semi-structured questionnaire. Fifty (50) informants were involved in providing information on the 65 plant species documented as medicinal plants and utilized by the residents to treat different kinds of diseases and ailments. The most frequently used plant part in terms of percentage of the total number of species was the leaves $(84.3 \%)$. This was followed by stem $(8.9 \%)$, roots $(7.1 \%)$, bark $(4.3 \%)$, hair and rhizome $(1.4 \%)$. The methods applied in the preparation of the herbal medicine were pounding, crushing, preheating, soaking, decocting and infusing. The most common health problems treated by the identified medicinal plants were stomach ailments, respiratory diseases, wounds, boils and muscle pains. Most of the medications were administered orally.
\end{abstract}

Keywords: Ethnobotany; Medicinal plants; Utilization; Common ailments

\section{Introduction}

Medicinal plants and herbs have been used for many centuries as a source of people's drugs for the treatment and prevention of diseases, disorders and the promotion of good health [1] and still provide the first line of primary health-care even in the present age to major segments of the population worldwide [2]. According to the World Health Organization (2003), it is estimated that up to $80 \%$ of the population depends exclusively on plants for their health and healing The information and folk knowledge regarding the medicinal and therapeutic uses of these indigenous plant materials have been handed down from generation to generation through verbal communication [3]. As modernization progresses however, the use of traditional medicinal plants has been threatened in many parts of the world. One of the major threats to these plants is that of habitat destruction. Due to modernization, natural vegetation is destroyed for the building of infrastructures that caters to the industrialization needs of the locale. Other concerns are those of over-harvesting of the plant medicine since vital parts of the plants are those that are used extensively causing their death and decrease in population [4]. Introduction of new western medicinal practices has resulted to the gradual replacement of traditional practices [5]. This is evident, nowadays, in the younger generations who do not possess as much knowledge of medicinal plants as the older generations [4].

With the growing threat of losing traditional knowledge in the modern era, many efforts have been made to record and publish this knowledge. In the past few years, a renewed interest on the natural method of treatment or traditional medicine arose worldwide. The work on ethno-medicinal knowledge has increased especially in some parts of Europe, Asia and Africa [6]. Despite many ethno-medicinal studies that were performed all over the world, a relatively few documentation on ethno-medicinal plant is done in the Philippines, in most cases focusing only on indigenous groups while the knowledge of traditional agriculturists and forest dwellers is neglected [7].

Northern Surigao del Sur in the Philippine archipelago is home to citizens who were descended from native and tribal groups influenced by the rapid modernization of the country. Most of the residents are farmers and fishermen who live near/on mountains, plains and farmlands, and on the coastal regions. These modernized dwellers have been practicing traditional folk medicine since time immemorial. With the advent of modern medicine and technology, the indigenous knowledge of herbal medicine and practices handed down from their forefathers has been threatened to extinction. Some of these folk medicines were relegated to the side-lines or are no longer practiced. With today's younger and more educated populace, knowledge or information of these traditional herbal medicines is no longer valued as being useful. This present study was conducted to document the knowledge of indigenous plant utilization and healthcare practices in the Northern part of Surigao del Sur. Findings of this research will provide a data base for future research and potential resource for the development of new drugs. It also provides a base for enhancing scientists' attention towards consideration of non-indigenous rural folks as source of ethno-botanical knowledge.

\section{Materials and Method}

Northern Surigao del Sur, comprising five districts, namely Carrascal, Cantilan, Madrid, Carmen and Lanuza, or collectively known as CarCanMadCarLan, lies in the northernmost coast of the province in the Philippines. Situated between latitudes $09^{\circ} 22^{\prime}-09^{\circ} 14^{\prime} \mathrm{N}$ and longitudes $125^{\circ} 56^{\prime}-126^{\circ} 04^{\prime} \mathrm{E}$, this piece of land is bordered by the Carrascal bay at the north and the Lanuza bay at the south with a total land area of 1097.71 square kilometers. The tropical region has vast timberlands mainly of coconut trees with over six thousand hectares of government-irrigated lands, seawaters in the east, and mountains in the west, north and south, having an average monthly precipitation of 257.2 millimeters. Aside from timberlands, it harbours mangrove forests, shrubs, and evergreens.

A barangay from each municipality was chosen purposively as

*Corresponding author: Gemma A Gruyal, Surigao del Sur State UniversityCantilan, College of Education Business and Management, Linintian, Cantilan Surigao del Sur 8317, Philippines - 083-212-5132, Tel: 9088838950; E-mail: gemma_gruyal@yahoo.com

Received March 03, 2014; Accepted June 19, 2014; Published June 22, 2014

Citation: Gruyal GA, del Roasario R, Palmes ND (2014) Ethnomedicinal Plants Used by Residents in Northern Surigao del Sur, Philippines. Nat Prod Chem Res 2 140. doi:10.4172/2329-6836.1000140

Copyright: $\odot 2014$ Gruyal G, et al. This is an open-access article distributed under the terms of the Creative Commons Attribution License, which permits unrestricted use, distribution, and reproduction in any medium, provided the original author and source are credited. 
study area and a prior informed permission was made through their Barangay chairman and some local administrators before the study was conducted. In each chosen barangay from the five municipalities, ten local residents (30-82 years old) served as informants, having wide knowledge on medicinal plants. Over all they were 50 people interviewed, 15 were male and 35 were females. They were interviewed via semi-structured questionnaires. The information gathered includes demographic profile like age, gender, the barangay where they belong and source of livelihood. Their knowledge on ethno-medicinal plants and its uses were also included. Interviews were conducted through informal conversations in order to allow for spontaneous replies and minimize feeling pressured. A series of interviews were made from October to March 2013, consolidated by field observations. The data acquired from each plant comprised the local name (Surigaonon name), the plant part used, its preparation and mode of administration and the ailment treated. Standard taxonomical procedures were used in gathering plant specimens, which were pressed, dried, identified and deposited in the herbarium at the Mindanao University of Science and Technology (MUST) and the student herbarium at the Institute of Biological Sciences, University of the Philippines Diliman. Photographs of every specimen were taken during the survey. Plant identification was carried by referring to various literatures such as [8-11].

\section{Results and Discussions}

The use of traditional medicine has been practiced in various countries since time immemorial [2]. In the Philippines, knowledge on the use of plants as medicine was inherited from great ancestors through oral tradition [6]. In the present study, a total of 65 plant species were documented as medicinal plants utilized by the Surigaonons. The species were classified into 44 families each treating different kinds of health disorders or ailments. Table 1 showed that Family Gramineae (4 species) and Verbenaceae (4 species) were represented as the highest number of species utilized as medicinal plant followed by Labiatea (3 species) and Malvaceae (3 species). Family Rutaceae, Apocynacea, Anacardiaceae, Fabaceae, Asteraceae, Euphorbiaceae, Solanaceae,
Myrtaceae and Zingiberaceae were represented by two (2) species each, while the rest of the families were all represented by one (1) species. In terms of habit, there are 22 species of herbs (33.9\%), 21 species of shrubs (32.3\%), 19 species of trees (29.2\%), and 3 species of climbers (4.6\%). Results indicated that the area has a diversity of plant species of medicinal value. Furthermore, because of the region is far from the city proper and their access to modern healthcare services is limited, most of the residents still resort to using traditional medicinal practices. Based on the results gathered, the leaves $(84.3 \%)$ are the most frequently used plant part for herbal medicine. This is also true in the studies of Del [12] among traditional healers in Southwest Cebu, Philippines and [6] on the Higaonon Tribe of Iligan City, Philippines wherein leaves were commonly prepared by boiling water (decoction) and administered orally. The frequent use of leaves helps in the survival and continuity of useful medicinal plants in Northern Surigao del Sur. It ensures the sustainability of the plants to grow in the area in order to cater to the needs of the rural populace for medicinal plants. However, in the studies of $[5,13]$ on the Temuans and by Ong and Nordiana [14] on the Malay villagers, the roots of the plants were the most utilized portion as herbal medicine. Other parts of the plants such as stems $(8.9 \%)$, roots $(7.1 \%)$, bark (4.3\%), hair and rhizome $1.4 \%$ and, fruits and seeds were often used in the preparations. The most common ailments were stomach discomfort due to diarrhea, respiratory diseases like common colds and cough, urinary tract infection and skin diseases. The preparation and administration of the medicinal plants varies based on the type of disease treated. The very common method of preparation was boiling the plant part or decoction until a desired concentration is achieved. Most of the treatments were administered orally. For immediate treatment like bleeding of wounds, leaves were pounded and crushed to extract the juice and applied topically or directly on the affected area.

As shown in Table 1, leaves are commonly used in treating ailments. However, the mode of administration varies from ailment to ailment as in the case of Lantana camara and Stachytarpheta jamaicensis $L$., wherein their leaves are boiled and used to clean wounds of the skin, while the leaves of Annona squamosal, Premna

\begin{tabular}{|c|c|c|c|c|c|c|c|}
\hline $\begin{array}{l}\text { Series } \\
\text { No. }\end{array}$ & Scientific Name & Family & Local Name & $\begin{array}{l}\text { Plant part } \\
\text { used }\end{array}$ & Preparation & Mode of Application & Ailment treated \\
\hline 1 & Anona muricata $\mathrm{L}$. & Anonacea & Guyabano & Leaves & Boil with water & $\begin{array}{l}\text { Drink one glass three times a } \\
\text { day, during ailment occur. }\end{array}$ & $\begin{array}{l}\text { Treat for diarrhoea, relief } \\
\text { stomach-ache }\end{array}$ \\
\hline 2 & Conyza cinerea L. & Asteraceae & Albahaka & Leaves & $\begin{array}{l}\text { Preheat the leaves, } \\
\text { extract the juice }\end{array}$ & $\begin{array}{l}\text { Rub or massage on the chest } \\
\text { and back. }\end{array}$ & To soften cough, "panuhot" \\
\hline 3 & Artemisia vulgaris $\mathrm{L}$. & Asteraceae & Hilbas & Leaves & $\begin{array}{l}\text { Preheat the leaves, } \\
\text { extract the juice }\end{array}$ & $\begin{array}{l}\text { Applied on the chest and back } \\
\text { to loosen the phlegm. }\end{array}$ & For cough and fever \\
\hline 4 & Annona squamosa $\mathrm{L}$. & Anonaceae & Atis & Leaves & Boil with water & $\begin{array}{l}\text { Drink thrice a day, induces } \\
\text { normal urination }\end{array}$ & Treat kidney infection \\
\hline 5 & $\begin{array}{l}\text { Artocarpus } \\
\text { heterophyllus Lam. }\end{array}$ & Moraceae & Nangka & Roots & Boil with water & Drink four times a day & $\begin{array}{l}\text { For diarrhoea, stomached } \\
\text { problem }\end{array}$ \\
\hline 6 & Aloe barbadensis Mill & Liliaceae & Sabila & Stem & Extract the sap & $\begin{array}{l}\text { Apply on the skin as } \\
\text { emollient. }\end{array}$ & For sun burn \\
\hline \multirow[b]{2}{*}{7} & \multirow[b]{2}{*}{ Amaranthus viridis $\mathrm{L}$. } & \multirow[b]{2}{*}{ Amaranthaceae } & \multirow[b]{2}{*}{ Hayom } & young leaves & Infusion of leaves & Drink during ailment occur & For stomach disorder. \\
\hline & & & & Leaves & Pound or crush the leaves & $\begin{array}{l}\text { Apply directly or topically on } \\
\text { affected area }\end{array}$ & Bruise and sprain \\
\hline 8 & Averrhoa carambola L. & Oxalidaceae & Balingbing & Leaves & $\begin{array}{l}\text { Crushed the leaves and } \\
\text { extract the juice. }\end{array}$ & $\begin{array}{l}\text { Rub and massaged all over } \\
\text { the body }\end{array}$ & $\begin{array}{l}\text { Lower body temperature } \\
\text { due to fever }\end{array}$ \\
\hline 9 & Blumea balsamifera & Compositae & Sagbong & Leaves & Boil with water & $\begin{array}{l}\text { Drink four times a day to } \\
\text { induce urination. }\end{array}$ & Treat kidney infection \\
\hline 10 & $\begin{array}{l}\text { Bryophyllum pinnatum } \\
\text { (Lam.) Oken }\end{array}$ & Crassulaceae & Anghelika & Leaves & Pound leaves until soft & $\begin{array}{l}\text { Apply and attach to the } \\
\text { affected area. }\end{array}$ & Relief of toothache \\
\hline \multirow[t]{2}{*}{11} & \multirow{2}{*}{ Biva orillana L. } & \multirow{2}{*}{ Bixaceae } & \multirow{2}{*}{ Sijotes } & Leaves & Leaves are heated & $\begin{array}{l}\text { Apply directly on the affected } \\
\text { area. }\end{array}$ & For sprain \\
\hline & & & & roots & Boil with water & $\begin{array}{l}\text { Drink Thrice a day to soften } \\
\text { cough }\end{array}$ & For cough \\
\hline
\end{tabular}


Citation: Gruyal GA, del Roasario R, Palmes ND (2014) Ethnomedicinal Plants Used by Residents in Northern Surigao del Sur, Philippines. Nat Prod Chem Res $2: 140$. doi:10.4172/2329-6836.1000140

Page 3 of 5

\begin{tabular}{|c|c|c|c|c|c|c|c|}
\hline 12 & Basella rubra L. & Basellaceae & Alugbati & Leaves & Crush the leaves & $\begin{array}{l}\text { Apply directly on affected } \\
\text { area }\end{array}$ & For boils \\
\hline 13 & Cymbopogon citratus & Gramineae & Tangyad & Leaves & Boil with water & Drink three times a day & Lower hypertension \\
\hline 14 & Coleus aromaticus & Labiatae & Garabo & Leaves & $\begin{array}{l}\text { Preheat the leaves and } \\
\text { extract juice with agridulsi }\end{array}$ & $\begin{array}{l}\text { Take one tablespoon three } \\
\text { times a day }\end{array}$ & Relief and soften cough \\
\hline 15 & $\begin{array}{l}\text { Citrus microcarpa } \\
\text { Bunge }\end{array}$ & Rutacea & $\begin{array}{l}\text { Agridulsi } \\
+ \\
\text { Garabo }\end{array}$ & $\begin{array}{l}\text { fruit juice } \\
+ \\
\text { Leaves }\end{array}$ & $\begin{array}{l}\text { Extract juice } \\
+ \\
\text { Preheat then extract juice } \\
\text { then mix. }\end{array}$ & $\begin{array}{l}\text { Take one tablespoon three } \\
\text { times a day }\end{array}$ & Relief cough \\
\hline 16 & Cassia alata L. & Fabaceae & Sunting & Leaves & Boil with water & As washing or antiseptic. & For athletes foot \\
\hline 17 & Coleus blumei & Labiatae & Mayana & leaves & Pound until soft and juicy & $\begin{array}{l}\text { Apply the leaves directly to } \\
\text { affected area. }\end{array}$ & For mumps \\
\hline 18 & Carica papaya L. & Caricaceae & Kapaja & Seeds & Seeds with water & Drink thrice a day. & As antihelmentic \\
\hline 19 & Curcuma longa L. & Zingiberaceae & Duyaw & Rhizome & $\begin{array}{l}\text { Preheat the rhizome and } \\
\text { extract the juice mixed } \\
\text { with coconut oil }\end{array}$ & $\begin{array}{l}\text { Apply directly on the affected } \\
\text { area. }\end{array}$ & Heals bruise and boils \\
\hline 20 & Centella asiatica L. & Umbelliferae & Jahog-jahong & $\begin{array}{l}\text { leaves and } \\
\text { stem }\end{array}$ & $\begin{array}{l}\text { Infusion of the leaves and } \\
\text { stem }\end{array}$ & Drink three times a day. & $\begin{array}{l}\text { For diabetes, stomach- } \\
\text { ache, amoeba }\end{array}$ \\
\hline 21 & Cocos nucifera L. & Palmae & $\begin{array}{l}\text { Nijog } \\
+ \\
\text { Kumentang }\end{array}$ & $\begin{array}{l}\text { roots } \\
+ \\
\text { Leaves }\end{array}$ & $\begin{array}{l}\text { Decoction of the roots } \\
\text { and a few number of } \\
\text { kumentang leaves }\end{array}$ & $\begin{array}{l}\text { Decoction of the roots and } \\
\text { a few number of kumentang } \\
\text { leaves }\end{array}$ & For arthritis \\
\hline 22 & Citrus aurantium $\mathrm{L}$. & Rutaceae & Kahel & young leaves & Crushed the leaves & Apply on the forehead. & Relieved headache \\
\hline 23 & Chromolaena odorata & Asteraceae & Hagonoy & leaves & $\begin{array}{l}\text { Pound leaves to soften } \\
\text { and extract the juice. }\end{array}$ & apply to affected area & For boils \\
\hline 24 & $\begin{array}{l}\text { Chrysophyllum cainito } \\
\text { L. }\end{array}$ & Sapotaceae & Kaymito & Leaves & Boil with water & Drink three times a day & $\begin{array}{l}\text { For diarrhoea, relief } \\
\text { stomach-ache }\end{array}$ \\
\hline 25 & Capsicum frutescens $\mathrm{L}$. & Solanaceae & Sili & Leaves & $\begin{array}{l}\text { Crush the leaves mix with } \\
\text { coconut oil. }\end{array}$ & rub on the chest & For asthma \\
\hline 26. & $\begin{array}{l}\text { Dasymaschalon } \\
\text { clusiflorum Merr. }\end{array}$ & Rutaceae & Tabog & Leaves & $\begin{array}{l}\text { Pound the leaves to } \\
\text { soften }\end{array}$ & Apply on the affected area. & For boils in the eye lid \\
\hline 27 & $\begin{array}{l}\text { Syzygium malaccense } \\
\text { L. }\end{array}$ & Myrtaceae & Bongogon & Leaves & Boil with water & $\begin{array}{l}\text { Drink four times a day to } \\
\text { induce urination }\end{array}$ & For kidney infection \\
\hline 28 & Euphorbia hirta L. & Euphorbiaceae & Tawa-tawa & $\begin{array}{l}\text { leaves and } \\
\text { stem }\end{array}$ & Boil in water & Drink three times a day. & For dengue fever \\
\hline 29 & $\begin{array}{l}\text { Eleusine indica (L.) } \\
\text { Gaetn }\end{array}$ & Graminae & Bila-bila & Leaves & Boil in water & Drink three times a day & As diuretic \\
\hline 30 & Ficus benjamina L. & Moraceae & Diyaket & Bark & $\begin{array}{l}\text { Preheat and pound the } \\
\text { bark }\end{array}$ & $\begin{array}{l}\text { Apply directly on affected } \\
\text { area. }\end{array}$ & For rheumatism \\
\hline 31 & Gmelina arborea Roxb. & Lamiacea & Gemilina & leaves & Pick fresh leaves & $\begin{array}{l}\text { Apply directly on chest and } \\
\text { stomach }\end{array}$ & $\begin{array}{l}\text { Relief muscle pain and can } \\
\text { induce flatulence due to } \\
\text { panuhot }\end{array}$ \\
\hline 32 & $\begin{array}{l}\text { Hibiscus rosasinensis } \\
\text { L. }\end{array}$ & Malvaceae & Gumamela & Bud & Pound until become soft & $\begin{array}{l}\text { Apply topically on affected } \\
\text { area. }\end{array}$ & $\begin{array}{l}\text { Heals swelling and as anti- } \\
\text { inflammatory agent }\end{array}$ \\
\hline 33 & Heliotropium indicum L. & Boraginaceae & Elepante & Leaves & Boil with water & Drink three times a day & $\begin{array}{l}\text { For diarrhoea and } \\
\text { stomach-ache }\end{array}$ \\
\hline 34 & Hyptis suaveolens Poir. & Lamiaceae & Pilodo & $\begin{array}{l}\text { leaves and } \\
\text { stem }\end{array}$ & Boil with water & Drink three times a day & As antispasmodic \\
\hline 35 & Imperata cylindrica & Graminae & Kogon & Roots & Boil with water. & $\begin{array}{l}\text { Drink four times a day to } \\
\text { induce urination }\end{array}$ & $\begin{array}{l}\text { for kidney infection and } \\
\text { stomach-ache }\end{array}$ \\
\hline 36. & $\begin{array}{l}\text { Impatiens balsamina } \\
\text { Linn. }\end{array}$ & Malvaceae & Suwangga & Leaves & Crushed the leaves & Apply as poultice & Cure scabies \\
\hline 37. & Jatropha curcas & Euphorbiaceae & Tuba-tuba & Stem & $\begin{array}{l}\text { scrape the stem preheat, } \\
\text { squeeze to produce juice }\end{array}$ & $\begin{array}{l}\text { Apply externally rub and } \\
\text { massaged on the body. }\end{array}$ & $\begin{array}{l}\text { Relief of flatulence or } \\
\text { panuhot that causes cough }\end{array}$ \\
\hline 38. & Kyllinga monocephala & Cyperaceae & Bosikad & $\begin{array}{l}\text { Stem and } \\
\text { leaves }\end{array}$ & $\begin{array}{l}\text { Soaking in water during } \\
\text { night time }\end{array}$ & Drink the water morning time. & $\begin{array}{l}\text { Relief headache, muscle } \\
\text { pain, fever }\end{array}$ \\
\hline 39. & Luffa acutangula L. & Cucurbitaceae & Patola & Leaves & Boil with water & Drink three times a day & $\begin{array}{l}\text { Treatment for } \\
\text { dysmenorrheal }\end{array}$ \\
\hline 40. & Leucaena glauca L. & Mimosaceae & Ipil-ipil & Seeds & & $\begin{array}{l}\text { Eat five seeds in every dose } \\
\text { for three days }\end{array}$ & As dewormer \\
\hline 41. & $\begin{array}{l}\text { Stachytarpheta } \\
\text { jamaicensis L. }\end{array}$ & Verbenaceae & $\begin{array}{l}\text { Kanding- } \\
\text { kanding }\end{array}$ & Leaves & Boil in water & $\begin{array}{l}\text { Used as washing and } \\
\text { antiseptic. }\end{array}$ & Cleaning of wounds \\
\hline 42. & Mangifera indica L. & Anacardiaceae & Manga & Bark & Boil with water & Drink three times a day & For dysmenorrheal \\
\hline 43. & Mimosa pudica L. & Fabaceae & $\begin{array}{l}\text { Hibi-hibi } \\
+ \\
\text { Amorsiko }\end{array}$ & Roots & Boil with water & Drink three times a day & Treatment for Goiter \\
\hline 44. & $\begin{array}{l}\text { Andropogon aciculatus } \\
\text { Retz. }\end{array}$ & Graminae & Amorsiko & Roots & Boil with water & Drink three time a day & Treatment for goiter \\
\hline
\end{tabular}




\begin{tabular}{|c|c|c|c|c|c|c|c|}
\hline 45 & Musa paradisiacal & Musaceae & Saging & Young leaves & & $\begin{array}{l}\text { Apply directly lower portion of } \\
\text { the stomach }\end{array}$ & $\begin{array}{l}\text { Give cooling effect, induce } \\
\text { normal urination or " bus- } \\
\text { aw" }\end{array}$ \\
\hline 46 & Moringa oleifera L. & Moringaceae & Kalamungay & Leaves & Crushes the leaves & Apply on the open wound & Abate bleeding \\
\hline 47 & $\begin{array}{l}\text { Manihot esculenta } \\
\text { Crantz }\end{array}$ & Euphorbiaceae & $\begin{array}{l}\text { Kamoting- } \\
\text { kahoy }\end{array}$ & Leaves & Boil with water & Use in bathing & After healing of measles \\
\hline 48 & Mentha arvensis & Labiateae & Helba buena & Leaves & Boil with water & Drink three times a day & For stomach discomfort \\
\hline 49 & Premna odorata Blanco & Verbenaceae & Adgao & Leaves & Boil with water & Drink four times a day & Relief and loosen cough \\
\hline 50 & $\begin{array}{l}\text { Pterocarpos indicus } \\
\text { Willd. }\end{array}$ & Fabaceae & Naga & Bark & $\begin{array}{l}\text { Scrape and squeeze the } \\
\text { sap }\end{array}$ & $\begin{array}{l}\text { Topically apply directly on } \\
\text { affected area }\end{array}$ & Relief for herpes simplex \\
\hline 51 & $\begin{array}{l}\text { Persea americana } \\
\text { Gaertn. }\end{array}$ & Lauraceae & Abukado & Leaves & Boil with water & Drink three times a day & $\begin{array}{l}\text { For diarrhoea, relief } \\
\text { stomach-ache }\end{array}$ \\
\hline 52 & Psidium guajava & Myrtacea & Bayabas & Young leaves & Boil with water & $\begin{array}{l}\text { Externally, used as washing } \\
\text { or antiseptic } \\
\text { Internally, drink three times } \\
\text { a day. }\end{array}$ & $\begin{array}{l}\text { Disinfect the wound, for } \\
\text { diarrhoea. }\end{array}$ \\
\hline 53 & Plumeria obtuse L. & Apocynacea & Kalatsutsi & Leaves & $\begin{array}{l}\text { Pound and extract the } \\
\text { juice }\end{array}$ & $\begin{array}{l}\text { Apply directly on the affected } \\
\text { area. }\end{array}$ & $\begin{array}{l}\text { Treatment for herpes } \\
\text { simplex }\end{array}$ \\
\hline 54 & $\begin{array}{l}\text { Premna cumingiana } \\
\text { Schauer }\end{array}$ & Lythraceae & Banaba & Leaves & Boil with water & $\begin{array}{l}\text { Drink three times a day to } \\
\text { induce urination. }\end{array}$ & For kidney infection. \\
\hline 55 & Pandanus odorata & Pandanaceae & Pandan tsina & leaves & Boil with water & Drink four times a day & $\begin{array}{l}\text { For cough, induce urine, } \\
\text { control cholesterol }\end{array}$ \\
\hline 56 & Portulacao leraceae L. & Piperaceae & Sinaw-sinaw & $\begin{array}{l}\text { leaves and } \\
\text { stem }\end{array}$ & Infusion of leaves & $\begin{array}{l}\text { Drink four times a day, induce } \\
\text { urination. }\end{array}$ & $\begin{array}{l}\text { For kidney infection, } \\
\text { arthritis }\end{array}$ \\
\hline 57 & Solanum melongena L. & Solanaceae & Biringhinas & Leaves & Boil with water & $\begin{array}{l}\text { External, gargle with a little } \\
\text { of salt }\end{array}$ & For swollen gums \\
\hline 58 & Symphytum officinale & Boraginaceae & Comprey & Leaves & Boil with water & Drink three times a day. & For cough and colds \\
\hline 59 & Tinospora reticulate & Menispermaceae & Panjawan & Stem & Boil with water & $\begin{array}{l}\text { Drink three times a day to } \\
\text { lower blood sugar. }\end{array}$ & For diabetes \\
\hline 60 & Vitex negundo L. & Verbenaceae & Lagundi & Leaves & Infusion of leaves & Drink three times a day. & For cough and colds \\
\hline 61 & Viola odorata L. & Violaceae & Bayoleta & $\begin{array}{l}\text { flower, stem, } \\
\text { leaves }\end{array}$ & $\begin{array}{l}\text { Infusion of flower, stem } \\
\text { and leaves }\end{array}$ & $\begin{array}{l}\text { Internally, drink three times } \\
\text { a day }\end{array}$ & $\begin{array}{l}\text { Treat digestive disorder, } \\
\text { for cough }\end{array}$ \\
\hline 62 & Muntingia calabura L. & Elaeocaraceae & Mansanitas & Young leaves & Infusion of leaves & Drink three times a day & $\begin{array}{l}\text { For diarrhoea, stomach- } \\
\text { ache }\end{array}$ \\
\hline 64 & $\begin{array}{l}\text { Zingiber officinale } \\
\text { Roscoe }\end{array}$ & Zingiberaceae & Luja & Rhizome & $\begin{array}{l}\text { Pound and extract the } \\
\text { juice and mixed with oil }\end{array}$ & $\begin{array}{l}\text { Rub on affected area to } \\
\text { induce gas pain. }\end{array}$ & For Stomach-ache \\
\hline 65 & Zea mays L. & Graminae & Mais & Young hair & Soak in water & $\begin{array}{l}\text { Drink three times a day to } \\
\text { stimulate urination. }\end{array}$ & For kidney trouble. \\
\hline
\end{tabular}

Table 1: List of medicinal plants used by residents in Northern part of Surigao del Sur.

odorata and Symphytum officinale, and the young leaves of Ziziphus jujube are boiled in water and taken orally to treat of kidney infection, common colds and cough, and diarrhoea, respectively. Results also show that leaves were mostly used to treat cough with different modes of application. The juice of Conyza cinerea $L$. extracted from the leaves is massaged on the chest and back (externally applied) to cure dry cough, while the leaves of Coleus aromaticus were preheated to extract the juice and taken orally (internally applied) three times a day to cure the same ailment. Other medicinal plants can be utilized to treat two or more diseases such as Pandan tsina which is used to treat cough and induce urination to relieve kidney trouble and Kyllinga monocephala (Bosikad) relieves headaches, muscle pain, and fever. In contrast, several species can also be used to treat the same ailments with the same mode of preparation, such as, decoction or boiling with water and taken orally as tea. Examples include Anona muricata L., Artocarpus heterophylles, Chrysophyllum cainito L. and Persia Americana G which all treat diarrhoea and relieve stomach-aches. However, parts of the plants used from each species differ to treat the same ailment. Other species can also be used to treat ailments with different modes of application. Psidium guajava is used externally as a disinfectant in wounds while it is also taken orally by the residents to cure diarrhoea. The infusion of young leaves of Amaranthus viridis L. used for stomach disorders is internally administered while matures leaves, for bruises and sprains, are topically applied on the affected area after extracting the juice by pounding. Some of the plants were utilized (both internal and external) in treating the ailments, however, the plant part used is different. For example, Bixa orellana leaves were preheated over fire and applied directly on the affected area to relieve sprain while its roots were decocted for the treatment of cough.

It was also observed that some of the preparations used roots to treat various ailments such as cough, stomach-ache, arthritis, goitre and kidney infection. Although roots have many uses, it was revealed in the survey that utilization of roots $(7.1 \%)$ is lesser compared to leaves $(84.3 \%)$. This indicates that many of the residents in Northern Surigao del Sur were careful of their flora and fauna knowing that extraction of the entire plant destructs to the environment and lowers the regeneration of medicinal plants caused by the trampling of habitat soil.

In the Philippines, other indigenous groups exhibited similar utilization pattern of medicinal plants used to treat certain diseases. For example, in the study of $[15,16]$, Kalanguyas in Tinoc Ifugao used the boiled leaves of Blumea balsamifera and rhizomes of Zingiber officinale to cure cough; and observed the boiled roots and young hairs of Imperata cylindrical and Zea mays, respectively, help cure people suffering from kidney infection, since these grasses induce normal urination. These medicinal plants, as documented in the study of Olowa et al. [6] are also utilized among in Higaonon Tribe of Rogongon. Moreover, the Tasaday of Mindanao, Kalanguyas of Ifugao, Higaonon 
Tribe of Rogongon used Psidium guajava as an antiseptic wash for wounds and other skin diseases [6]. Traditional healers of Southwest Cebu also used Cymbopogon citratus and Euphorbia hirta L. leaves to lower hypertension and cure dengue, respectively. These are similarly utilized by the residents of the Northern part of Surigao del Sur.

Based on the studies mentioned above, indigenous groups in the Philippines exhibit similar utilization of medicinal plants in treating specific ailments. However, several species studied in this paper are used by the subjects differently from those in other indigenous groups. Examples include Eleusine indica which is used by traditional healers in Cebu to treat back pains and fractures [12], but is utilized by Surigaonons as a diuretic; Persea Americana leaves which are boiled and decocted to treat kidney stones of Cebuanos [12], but used in Surigao del Sur to cure diarrhea and relieve stomach-aches; and Annona squamosa $L$., which for Higaonons, is a cure for diabetes and rheumatism but a kidney infection medicine for the inhabitants of Northern Surigao del Sur. The difference in the usage of medicinal plants to treat specific ailments may probably be because of the different geographical location of inhabitants and their dissimilar ways of living and exposure to diseases. Generally, however, even with these differences in usage, different indigenous groups or even rural communities in the Philippines exhibit a similar way of valuing indigenous knowledge on traditional medicine which is intrinsic among them and inherited from their great ancestors.

The inhabitants from the Northern part of Surigao del Sur treated many types of ailments ranging from simple health problems such as skin diseases and stomach-ache to chronic diseases like diabetes, hypertension and goitre. Such knowledge can provide a basis for further scientific studies on the efficacy and search for bioactive components found in plants. However, there is still a need to test the active component of these medicinal plants in terms of its pharmacologic effects. According to Ong [5] it is important not only to record such ethno-medical knowledge and conduct further studies but also to take steps in conserving these medicinal plants before they are lost forever. The present study, affirms this idea since, Surigao del Sur particularly in the Northern part of the province, has several mining activities. With the advent of the mining industry in the area several plant species which are the subject of this study will be decimated due to the destruction of the forest or the plants natural habitat. Thus, if this knowledge is not documented, the plants utilized, especially those high in medicinal value, may become extinct.

\section{Conclusion}

This study shows that there is a prevailing knowledge on the traditional uses of medicinal plants treating certain ailments and health problems among the residents in the Northern part of Surigao del Sur. Most of the ailments treated in the region are cough, diarrhea and stomach ache, and kidney infection. The use of leaves indicates that many of the residents in Northern part of Surigao del Sur were careful to the extent of survival of medicinal plants. Results of this study suggest that rural folks should also be considered as important source of information about the use of medicinal plants. This study records not only the ingenuity of the Surigaonons on their use of various medicinal plants and traditional healthcare practices but documents the invaluable knowledge of the forefathers of the inhabitants so that it may survive amidst the rapid modernization of the country.

\section{Acknowledgement}

We are grateful to thank for the financial support granted by the research section of Surigao del Sur State University, Cantilena. Special thanks also to all the respondents who have shared their knowledge on the medicinal plants.

\section{References}

1. Alpuerto AFT, Bangaysiso A, Galang V, Maquiling L, Taylor, et al., (2010) Level of awareness and extent of utilization of the ten medicinal plants approved by the department of health. Nursing Research Journal 2: 73-92.

2. Khatun A, Or-Rashid H, Rahmatullah M (2011) Scientific Validation of Eight Medicinal Plants Used in Traditional Medicinal Systems of Malaysia: A Review. American-Eurasian Journal of Sustainable Agriculture 5: 67-75.

3. Hossan S, Hanif A, Agarwala B, Sarwar S, Karim M, et al., (2010) Traditional Use of medicinal Plants in Bangladesh to Treat Urinary Tract Infections and Sexually Transmitted Diseases. Ethnobotany Research \& applications 8: 061-074.

4. Caniago I, Siebert F (1998) Medicinal plant ecology, knowledge and conservation in Kalimantan, Indonesia. Economic Botany 52: 229-250.

5. Ong HC, Chua S, Milow P (2011) Ethno-medicinal Plants Used by the Temuan Villagers in Kampung Jeram Kedah, Negeri Sembilan, Malaysia. Ethno Med 5: $95-100$.

6. Olowa LF, Torres MA, Aranico EC, Demayo CG (2012) Medicinal Plants Used by the Higaonon Tribe of Rogongon, Iligan City, Mindanao, Philippines. Advances in Environmental Biology 6: 1442-1449.

7. Langenberger GK, Martin, Prigge V (2005) Ethnobotanical Survey among Farmers in Leyte, Philippines, and Comparison with Indigenous Filipino Plant Lore. Conference on International Agricultural Research for Development, Stuttgart-Hohenheim.

8. Madulid DA (1995) A Pictorial Cyclopedia of Philippine Ornamental Plants. Metro Manila, Philippines: Bookmark, Inc.

9. Madulid DA (2001) Dictionary of Plant Names. Local Name-Scientific Name Makati City, Philippines. The Bookmark Inc.

10. Merrill ED (1903) A Dictionary of the Plant Names of the Philippine Islands Manila; Bureau of Public printing.

11. Quisumbing E (1978) Medicinal Plants of the Philippines, Katha Publishing Co Inc. WHO, 2003. Traditional Medicine, WHO, Geneva.

12. Del Fierro R, Nolasco F (2013) An Exploration of the Ethno-Medicinal Practices among Traditional Healers in Southwest Cebu, Philippines. ARPN Journal of Science and Technology 3: 1182-1187.

13. Ong HC (1994) The Practice of traditional Medicine among the Temuan Orang Asli-an Indigenous tribe in Malaysia, Wallaceana, 72: 1-5

14. Ong HC, Nordiana M (1999) Malay Ethno-medico Botany in Machang Kelantan, Malaysia, Fitoterapia. 70: 502-513.

15. Balangcod TD, Balangcod AKD (2011) Ethnomedical Knowledge of plants and healthcare practices among the Kalanguya tribe in Tinoc, Ifugao, Luzon Philippines. Indian Journal of Traditional Knowledge 10: 227-238.

16. Yen DH, Guttierrez HG (1974) The Ethnobotany of the tasaday: the useful plants. Philippine journal of Science 103: 97-140. 